\title{
Nuda egzystencjalna a sensowny wymiar człowieka
}

DOI: http://dx.doi.org/10.12775/RF.2016.027

„Poznałem życie po bieganinie nieszczęsnych ludzi, rojących się w tych pokoikach i korytarzach, po głosach zachrypniętych i piskliwych, po meblach biurowych czarnych i obdrapanych, po zakurzonych podłogach"**.

W tej pracy odniosę się przede wszystkim do interpersonalnej, relacyjnej wykładni pojęcia sensu Viktora Emila Frankla ${ }^{1}$ oraz do wykładni nudy przedstawionej w prozie psychologicznej Alberto Moravii. Celem tego artykułu jest przedstawienie kluczowej kategorii nudy, która stanowi esencję życia bezsensownego i pozbawionego znaczenia. Zwrócę uwagę na to, że nużącą (skostniała) postawa wobec życia kształtuje zachowanie oportunistyczne, zachowawcze, bierne i egoistyczne. W dalszych częściach artykułu postaram się wykazać, że pojęcie nudy (u Moravii) skorelowane jest z poczuciem braku sensu w życiu, co skutkuje niemożnością wyjścia poza własny wyalienowany świat. Moravia ukazuje nam jednowymiarowe ujęcie pojęcia nudy, która doprowadza do wewnętrznego zlodowacenia, jednostajności i odrętwienia. Związane jest to ze stanem neutralności aksjologicznej czy srogiej obojętności, wynikającej

A. Moravia, Rzecz jest tylko rzecza, wyd. Czytelnik, Warszawa 1969, s. 35.

1 Twórca trzeciej szkoły psychoterapii, logoterapeutycznego modelu życia i analizy egzystencjalnej. Część swojego życia spędził w obozie koncentracyjnym, co miało duży wpływ na wykształcenie w nim określonych poglądów. Wychodził z założenia, że człowiek jest istotą wolna, ale i odpowiedzialna, co predestynuje go do postawy aktywnej życiowo. 
ze zderzenia jednostki z rzeczywistością społeczną, co może skutkować egzystencjalnym lękiem i frustracją. Viktor Frankl przeciwstawia się tej katastroficznej wizji człowieczeństwa, albowiem wielokrotnie podkreśla, że ludzka egzystencja ma charakter procesualny i sensowny, co oznacza, że nuda może być traktowana tylko i wyłącznie - zdaniem tego myśliciela - jako akcydentalna cecha każdego człowieka wynikająca z jego niedoskonałości. Według wiedeńskiego psychologa istotne oraz konstruktywne związki z drugim człowiekiem prowadzą do rozbudowania noetycznego 2 wymiaru osobowości (psycho-fizyczno-duchowy) ${ }^{3}$. Jednak częstokroć $\mathrm{w}$ wyniku rozbicia jaźni, poprzez różne dotkliwe doświadczenia, może dojść do tego, że mechanizmy obronne zablokują w nas motywację i uniemożliwią otwarcie się na drugiego. Ennui to przeżywanie stanu wewnętrznego braku, skostnienia oraz inercji ${ }^{4}$. Marcin Zdrenka wskazał na podobieństwo między gnuśnością a nudą. Interesujące jest zwrócenie uwagi na lenistwo entropiczne, które interpretowane jest przez Zdrenkę jako marnotrawienie energii ${ }^{5}$. Magdalena Bizior-Dombrowska w swym artykule ${ }^{6}$ stwierdza, że przed XVIII wiekiem pojęcie nudy było utożsamiane $\mathrm{z}$ odczuciem fizjologicznym jako „nudność" i „złe samopoczucie” oraz „nędza”. Autorka ta odwołuje się również do powtarzalności zjawisk, które tkwią w naturze nudy i „nudzenia się", o czym wspomina przede wszystkim Josif Brodski w swej Pochwale nudy ${ }^{7}$. Nuda - jak podkreśla Bizior-Dombrowska - charakteryzuje się przesytem, albowiem rzeczywistość dla osoby nudzącej się nie ma określonej wartości, nie powoduje żadnych stanów emocjonalnych, stanowi pustą przestrzeń. Wszystko wydaje się rozmazane i nieprecyzyjne ${ }^{8}$. „Nuda jest zatem jednoznaczna z zamknięciem i ignorancją świata" ${ }^{\prime \prime}$.

2 Termin noetyczny został wprowadzony przez badacza myśli Frankla - Kazimierza Popielskiego. Noetyczny wymiar ludzkiej egzystencji wskazuje na to, że człowiek jest istotą duchowa co znaczy, że ludzki byt nie jest konstytuowany tylko przez aspekt psycho-fizyczny. Warto podkreślić, że w artykule odwołuje się do ściśle psychologicznego odniesienia do terminu „noetyczny”.

3 Zob. K. Popielski, Noetyczny wymiar osobowości. Wydawnictwo Uniwersyteckie KUL, Lublin 1994.

4 S. Stępień, Romantyczna nuda i nowoczesna świadomość. Adam Mickiewicz - George Gordon Byron. Próba paraleli, „Wiek XIX Rocznik Towarzystwa Literackiego im. Adama Mickiewicza, rok VIII (I.) 2015, s. 238.

5 M. T. Zdrenka, Próba problematyzacji przywary gnuśności, „Ruch Filozoficzny”, LXVIII, 2011, 2, s. 387-394.

6 M. Bizior-Dombrowska, Nuda jako źródło zła w ujęciu Sørena Kierkegaarda, w: Koncepcje i problemy filozofii zła, red. R. Wiśniewski, M. Jaranowski, Wydawnictwo Naukowe Uniwersytetu Mikołaja Kopernika, Torun 2009, s. 51.

7 Ibidem, s. 66.

8 Ibidem, s. 54-55.

9 Ibidem, s. 55. 
Interesującego obrazu znudzenia dostarcza powieść Sōseki Natsume ${ }^{10}$ Sedno rzeczy, w której główni bohaterowie (na skutek bolesnej przeszłości) naznaczeni są stanem ambiwalencji emocjonalnej, której nie są w stanie zniwelować. Dwóch przyjaciół nie jest w stanie komunikować się ze sobą, ponieważ obaj zakochali się w jednej kobiecie.

Mimo powtarzających się drobnych rozczarowań nigdy nie przyszło mi na myśl, żeby z tego powodu zerwać z nim znajomość. Raczej przeciwnie, gdy targał mną niepokój, zawsze pragnąłem jeszcze bardziej ją pogłębić. Wraz z rosnącą zażyłością - myślałem - kiedyś wyraźnie objawi mi się to, czego oczekuję ${ }^{11}$.

Jak wynika z powyższych zdań, nie wszystkie stany wewnętrzne jesteśmy $w$ stanie zwerbalizować. Jednak trwanie, jak w tym przypad$\mathrm{ku}, \mathrm{w}$ relacji przyjacielskiej, pomimo postępującego zgorzknienia jednego z bohaterów, może doprowadzić do terapeutycznego przebudzenia i rozbicia krępujących kajdan braku zaufania.

To, że nie potrafiłem tego uczynić, wynikało z pewnego rodzaju inercji kryjącej się w naszej przyjaźni, której główny ton nadawały elementy intelektualne, mnie zaś zabrakło odwagi, żeby zdecydowanie i otwarcie przełamać wyznaniem ustalony schemat naszych stosunków ${ }^{12}$.

Szczelne zamknięcie się na relację z drugim człowiekiem może krańcowo, poprzez absurdalny lęk, doprowadzić do tego, iż interakcje nie będą miały charakteru spontanicznego. Będą usztywnione poprzez niewypowiedzianą ograniczającą kodeksowość bądź poprzez obawę, że drugi człowiek nie będzie $\mathrm{w}$ stanie nas zrozumieć. $\mathrm{W}$ tym momencie kategoria samotranscendencji ${ }^{13}$ powoli zanika, pozostawiając po sobie tłum. międzyludzkich niedopowiedzeń. By uniknąć tego typu społecznych „waśni”, Frankl podpowiada, że należy mieć świadomość tego, iż życie jest napięciem między realnością a ideałami. Ludzie odpowiadają na pytania dotyczące własnej egzystencji dzięki działaniu. W każdej życiowej sytuacji - jako podmiot sprawczy - decyduję o tym, czy moje zakotwiczenie w świecie będzie miało charakter zobojętnienia i bezwładu czy też twórczej aktywności.

10 Sōseki Natsume napisał enigmatyczną i filozoficzną powieść zatytułowaną Kokoro [Sedno rzeczy], która ma wydźwięk egzystencjalny i melancholijny. Nuda ukazana jest tutaj jako brak umiejętności porozumiewania się. Stanowi przestrzeń, której główni bohaterowie nie są w stanie „przeskoczyć”.

11 N. Sōseki, Sedno rzeczy, Państwowy Instytut Wydawniczy, Warszawa 1973, s. 5.

12 Ibidem.

13 Samotranscendencja to kategoria wprowadzona przez twórcę psychologii sensu (logoterapii) Viktora Emila Frankla. Oznacza ona, że człowiek nieustanne przezwycięża niemoc twórcza, dążąc do przekraczania własnych niedoskonałości. 
U Martina Heideggera znudzenie porównane zostało do ciągnącego się trwania $\mathrm{W}$ czasie, jest utożsamiane $\mathrm{z}$ pewną formą obojętności. W związku z definicją podaną poniżej można wywnioskować, że nuda doprowadza do rozświetlenia bytu:

Głębokie znudzenie, ciągnące się Jak milcząca mgła w przepaściach naszej przytomności, pokrywa rzeczy i pokrywa ludzi, i wraz z nimi pokrywa nas samych - sprawiając, ze wszystko to po równi staje się nam osobliwie obojętne. W znudzeniu tym ujawnia się całość bytu ${ }^{14}$.

Jak w wyblakłym, pozbawionym nastrojów „szarym dniu powszednim" znajdować jakiś sens czasowy? I jak jest z czasowością nastrojów i uczuć takich jak nadzieja, radość, zachwyt, wesołość? Nie tylko lęk i trwoga są egzystencjalnie ufundowane w byłości, ale i inne nastroje; wystarczy tu przywołać takie fenomeny, jak znudzenie, smutek, melancholia, zwątpienie ${ }^{15}$.

Alberto Moravia w swojej powieści zatytułowanej Nuda pragnie wskazać, że tytułowe pojęcie nudy stanowi negację sensu jako postawy wzrostu. Nuda odzwierciedla stan atrofii woli i zawieszenia w przestrzeni społecznej i ontologicznej. Główny bohater (Dino) tej psychologicznej prozy jest przesiąknięty egzystencjalną nuda, która nie jest równoznaczna ze stanem praktycznej pasywności ${ }^{16}$. Nuda jest raczej odzwierciedleniem jednolitej, przyciemnionej i gasnącej chęci relacyjnego współbycia.

Czytamy:

Nuda to dla mnie typ niedopełnienia czy niedopasowania, czy niedomiaru rzeczywistości. Metaforycznie można by powiedzieć, że kiedy się nudzę, rzeczywistość kojarzy mi się niepokojąco ze spaniem pod zbyt krótką kołdrą w zimową noc - otulam nią nogi i marznę na piersi. Naciągam ją na pierś i lodowacieją mi nogi; $w$ ten sposób nigdy nie jestem stanie zasnąć. A jednak, odwołując się do innego porównania, moja nuda przypomina częste i tajemnicze przerwy w dopływie prądu do mieszkania - w jednym momencie wszystko jest jasne i wyraźne, tutaj stoją fotele, tutaj sofy, w głębi znajdują się szafy, komody, obrazy, zasłony, dywany, okna, drzwi, a potem nagle zostaje tylko ciemność i pustka ${ }^{17}$.

14 Zob. M. Heidegger, Czym jest metafizyka?, wprowadzenie, przekł. K. Wolicki, Warszawa 1977.

15 M. Heideger, Bycie i Czas, przekł. Bogdan Baran, Wydawnictwo Naukowe PWN, Warszawa 1994, s. 483-484.

16 Frankl odwołałby się do nerwicy noogennej. Związana jest ona z utratą chęci do działania oraz z zachowaniem neutralności wobec losu, wówczas człowiek oddala się od wyznaczonego sensu, dlatego życie przestaje mieć znaczenie i człowiek popada w pułapkę gnuśności.

17 A. Moravia, Nuda, Nowy Kanon, Warszawa 2010, s. 20. 


\section{Oraz:}

Nuda polega przede wszystkim na braku komunikacji. Dlatego też nie mogąc porozumieć się z matka, od której byłem oddzielony bariera, tak samo jak od wszystkich innych przedmiotów, musiałem poniekąd pogodzić się z nieporozumieniem i kłamać18.

Niewątpliwie, ukazane powyżej wątki postępującej abulii, inercji, alienacji, interpersonalnej i intrapsychicznej samotności otępiałego egzystencjalnie Dino, doprowadzają tego targanego sprzecznościami bohatera do chorobliwej antypatii wobec Cecylii, z którą spędza czas na erotycznej kompulsji, która nie daje duchowego i sensownego wytchnienia, wręcz doprowadza do rozpaczy, rozdarcia i skostnienia duszy. Czyżby tytułowa „nuda” stanowiła inną postać choroby ponowoczesności, która przejawia się wszechobecną apatią i znieczulicą emocjonalną która może stanowić solidną podstawę do tworzenia konformistycznych i egoistycznych cech?

Włoski pisarz przedstawia nam świat związków pełnych sprzeczności i niedopełnienia, co skutkuje brakiem otwartości i emocjonalnej intymności. Ten dyskurs relacyjności ma charakter płynny ${ }^{19}$, nie daje się wrzucić w sieć systemu, skonkretyzować, ujednolicić. Płynna nowoczesność przejawia się przede wszystkim w braku stałego odniesienia w życiu, trwałych relacji interpersonalnych czy systemu wartościowania świata. Lęk i elastyczność to dwa pojęcia splecione nierozerwalnie ze sobą. Destrukcyjny lęk, hamujący możliwość spontanicznego myślenia i działania, doprowadza do wycofania społecznego i zaniku chęci uczestniczenia w teatrze zawodowego wyścigu szczurów. Lęk nie istniałby bez elastyczności, a elastyczność bez lęku. By odnaleźć się w świecie, w którym nieprzerwanie zmieniane są reguły gry, konieczna jest odwaga i trud, by dokonać transgresji, czyli przekroczenia własnych niedoskonałości. Rynek pracy cechuje się bezwzględnością i nieprzewidywalnościa, dlatego też warto wyposażyć samego siebie w określone narzędzia czy kompetencje, które pomogą przezwyciężyć niepokój o przyszłość swoją i bliskich. Należy pamiętać o tym, że osobowość to zespół stałych właściwości i dyspozycji, które nabyliśmy w dzieciństwie i dookreślamy w całym późniejszym życiu. Sztywne zakotwiczenie w zespole tych trwałych cech może wywołać w konsekwencji poczucie pustki i nudy egzystencjalnej.

Egzystencja u Moravii cechuje się hybrydycznościa, jest zagmatwana, nieokiełznana, nie da się jej do końca opisać. Główny bohater Nudy nie potrafi sobie poradzić $\mathrm{z}$ natrętną stroną nudy oraz jej etycznymi

18 Ibidem, s. 22.

19 Zob. Z. Bauman, Płynna nowoczesność, Wydawnictwo Literackie, Kraków 2006. 
konsekwencjami. Dino wdaje się w romans z młodszą od siebie Cecylia, która bezpośrednio i nieskrycie manipuluje jego zachowaniem. Nuda $\mathrm{w}$ tym wypadku wiąże się z relacją sadomasochistyczną. Bohaterowie nie są w stanie wejść w zdrową satysfakcjonująca, symetryczną koegzystencję, albowiem cechuje ich zgorzknienie i rozczarowanie. Jest ona uosobieniem gorączkowej, anankastycznej aktywności, która nigdy nie doprowadzi do zaspokojenia, co rodzi bezsens. Kochanka staje się dla Dina obsesyjnym przedmiotem, którego nie może i nie potrafi usidlić, instrumentalne traktowanie, zagarnięcie, posiadanie doprowadza do szaleństwa, zaś nuda ukazuje tutaj stadium komunikacyjnej degradacji.

Nudząc się kluczowy bohater doświadcza Sarte'owskiego absurdu świata (referencja do Sartre'a). Chcąc zjednoczyć się ze swoją kochanką marzy o tym, aby neurotyczna miłość okazała się swoistym antidotum na egzystencjalne nudności. Karen Horney w swym dziele Neurotyczna osobowość naszych czasów podkreśliła, że związki sadomasochistyczne oparte są na redukcji lęku podstawowego, który uniemożliwia samodzielne sterowanie własnym życiem. Neurotycy nie potrafią zawierać satysfakcjonujących relacji, gdyż mają wyidealizowany obraz partnera. Zafałszowane jest ich pojęcie "miłości własnej”, mają niskie poczucie własnej wartości bądź cechuje ich destrukcyjny narcyzm ${ }^{20}$.

Bohaterowie powieści Moravii „ocierają się” tylko o siebie, poniżaja, nic dla siebie nie znacząc, cechuje ich ponowoczesne odrętwienie i egzystencjalny letarg, co powoduje, że żyją jednowymiarowo, prostolinijnie, bez wyższych uczuć i wzruszeń. Nuda spowinowacona jest z próżnią i frustracją egzystencjalną. Nudna egzystencja prowadzi do poczucia pustki, jest stanem wegetatywnego „zawieszenia”, znużenia, zmęczenia zastanym stanem rzeczy. Frustracja występuje wtedy, gdy człowiek nie jest w stanie poradzić sobie z nudą i bezradnością z niej wynikającą. Monadyczny, zindywidualizowany aspekt kontaktów interpersonalnych zagłusza fundamentalne pragnienie bliskości, zrozumienia, empatycznej koegzystencji. Jak widzimy u jednego z bohaterów ze zbioru krótkich opowiadań, pt. Rzecz jest tylko rzecza Moravii:

I przede wszystkim chcę, abyś wiedziała, że ja, wewnątrz, jestem jak góra lodowa, jak grota, jak podziemna maszyna: mojej większej części się nie widzi, to, co się widzi, to tyle, co nic. I chcę, Bello, abyś poznała to moje ukryte wnętrze, które, jeżeli mnie pokochasz, zdeklaruje się wreszcie i objawi ${ }^{21}$.

Inercja, apatia, brak podmiotowości sprawczej, odpowiedzialność rozproszona, postępująca infantylizacja, idealizacja pozbawiają bohate-

20 Zob. K. Horney, Neurotyczna osobowość naszych czasów, Rebis, Poznań 2006.

21 A. Moravia, Rzecz jest tylko rzecza, wyd. Czytelnik, Warszawa 1969, s. 43. 
rów realnych cech, by w ramach myślenia życzeniowego nabrać charakteru ciekłego, bezkształtnego ${ }^{22}$. Sigmund Freud powiedziałby, że egzystencja Dino pozostaje w sferze nieświadomości oraz że to właśnie ona warunkuje jego sposób bycia. „Pojęcie nieświadomości uzyskaliśmy $\mathrm{z}$ teorii wyparcia. Treści wyparte są dla nas modelem nieświadomości. Widzimy jednak, że mamy dwojakiego rodzaju nieświadomość - latentna, zdolną do uświadomienia, oraz treści wyparte, z racji swej natury same w sobie bezwzględnie niemożliwe do uświadomienia" ${ }^{23}$. Twórca psychoanalizy stworzył koncepcję libido, która związana jest zasada przyjemności, sublimacją nieświadomych popędów i eksplozją energii seksualnej. Nawiązując do psychologii integralnej Carla Junga możemy tutaj podkreślić, że bohaterowie powieści Moravii nie przeszli procesu indywiduacji, ich ego jest zafałszowane, ponieważ świadomość każdego z bohaterów jest egotyczna i narcystyczna, przez co proces rozwojowy zostaje zahamowany i jednostki nie mogą przebić się przez mur fiksacji i skupienia tylko na samych sobie ${ }^{24}$.

Obiektywność to spełniona indywiduacja. To odstąpienie od sądów wartościujących i od tego, co nazywamy przywiązaniem uczuciowym, na którym człowiekowi na ogół bardzo zależy. Otóż przywiązanie uczuciowe zawsze zawiera projekcje, a właśnie chodzi o to, żeby projekcje wycofać, by dotrzeć do samego siebie i do obiektywności. Związki uczuciowe są związkami pożądania, a jako takie obciążone są przymusem i zależnością: czegoś się od kogoś innego oczekuje, w ten zaś sposób i ten ktoś, i my tracimy wolność. Poznanie obiektywne jest możliwe poza uwikłaniami uczuciowymi - wydaje się, że to ono stanowi główną tajemnicę ${ }^{25}$.

Wszystko przypomina tutaj życie Sama Lowry'ego głównej postaci surrealistycznego filmu Terry'ego Gilliama, pt. Brazil. Sam próbuje wyrwać się ze szponów nieautentycznej egzystencji, w którą został wrzucony. Wrażliwy, refleksyjny, marzycielski ton jego życia zostaje doszczętnie zniszczony przez informatyzację i technologizację życia społecznego, co zostaje zobrazowane $\mathrm{w}$ interakcjach anonimowości i wrogości. Zmiażdżona zostaje jednostkowość w imię kolektywnego postępu i antykrytycyzmu, głównie pseudosensu, który winien przyoblekać twarze wszystkich osób żyjących, bez względu na to, czy czują się wewnętrznie ku temu predestynowani.

22 Ibidem.

23 S. Freud, Poza zasada przyjemności, Wydawnictwo Naukowe PWN, Warszawa 2005, s. 61.

24 Zob. C.G. Jung, Archetypy i nieświadomość zbiorowa. Wydawnictwo KR., Warszawa 2011.

${ }_{25}$ C.G. Jung, Wspomnienia, sny, myśli, WROTA i KR., Warszawa 1993, s. 349. 
Powołując się na Viktora Frankla, można rzec, że jego wciąż obecna teza o "patologii ducha czasu", znajduje tutaj swoje uzasadnienie. W swych pracach zwraca on uwagę na cztery postawy charakteryzujące współczesnego człowieka, które mogą doprowadzić do frustracji egzystencjalnej.

1. Nastawienie prowizoryczne: odnosi się do braków komunikacyjnych u ludzi. Istnieje problem w braku autentyczności, co w konsekwencji sprowadza się do stagnacyjnej postawy względem siebie i innych.

2. Fatalistyczna postawa życiowa: zwraca uwagę na to, że człowiek o nastawieniu fatalistycznym względem swoich potencjalności, rzeczywistości zewnętrznej oraz wewnętrznej, innych ludzi ostatecznie kreuje w swym umyśle rzeczywistość, która doprowadza do biernej postawy w obszarze życia społecznego. Fatalizm odnosi się do tego, że człowiek myśli, iż jego zachowanie jest całkowicie zdeterminowane przez czynniki zewnętrzne.

3. Myślenie kolektywistyczne: Jeśli powyższe postawy zostaną nieświadomie przyjęte przez ludzi, to ciężko nam będzie postrzegać siebie nawzajem w aspekcie personalnym i zindywidualizowanym. Myślenie zbiorowe wyklucza osobistą odpowiedzialność, doprowadza do jej rozproszenia.

4. Fanatyzm: Osoby o usposobieniu fanatycznym ignorują nie tylko swoją tożsamość, cechy niedoskonałości, ale przede wszystkim deprecjonują ludzi myślących w odmienny sposób, w taki, który w ich mniemaniu im zagraża ${ }^{26}$.

Wszystkie powyższe cechy dadzą się, zdaniem Frankla, sprowadzić do ucieczki od odpowiedzialności oraz lęku przed wolnością. Ten wiedeński psycholog stwierdza, iż może być to przyczyną narastającej nudy spowodowanej narzucająca się duchowością. Nuda stanowi tutaj kategorię odrzucenia i zanegowania cech duchowości, czyli porzucenia absolutystycznego systemu etycznego na rzecz pluralizmu aksjologicznego. Nuda rodzi się, gdy człowiek zauważa, że boi się bliskości, jest to forma ucieczki od zaangażowania i odpowiedzialności za drugiego człowieka. Frankl wychodzi z założenia, że prościej jest zachowywać się apatycznie i neutralnie niż wchodzić $\mathrm{w}$ wymagające i trudne związki. To znużenie noetycznym wymiarem człowieczeństwa jest istotą współczesnego kryzysu wartości ${ }^{27}$.

Także czeski pisarz Milan Kundera zwraca szczególną uwagę na tematykę związaną z interakcjami społecznych. Ten filozofujący prozaik w sposób niezwykle alegoryczny stara się wyłuskać sedno tajemnicy międzyludzkich zależności. Bohaterowie jego powieści osaczeni są

26 V.E. Frankl, Homo Patiens, PAX, Warszawa 1984, s. 59-61.

27 Zob. V.E. Frankl, Człowiek w poszukiwaniu sensu, Czarna Owca, Warszawa 2009. 
przez „tkliwą nieczułość tego świata” 28 , dlatego też bezwiednie zamykają swoją emocjonalność na oddziaływanie innych.

Wyobrażam sobie uczucia dwóch osób, które spotykają się po latach. Niegdyś przebywali ze sobą i myśla, że łączy ich to samo doświadczenie, te same wspomnienia. Te same wspomnienia? Tu właśnie zaczyna się nieporozumienie: nie mają tych samych wspomnień; oboje ze swych spotkań zachowują w pamięci parę drobnych sytuacji, lecz każde z nich inne; ich wspomnienia nie są podobne, nie stykają się ${ }^{29}$.

Frankl zauważył, iż część ludzi skrzętnie ukrywa swoje autentyczne uczucia oraz pragnienia. W czasach postępującej informatyzacji i ekonomizacji życia społecznego najbardziej pożądanym i najbardziej nagradzające jest podejście na zasadzie „,szkiełka i oka”. Niemiecki psycholog Peter Lauster odwołuje się do twórcy psychologii postaci Fredericka Perlsa, który trafnie spuentował: „Nawet tysiąc sztucznych kwiatów nie ożywi pustyni. A tysiąc pustych twarzy nie zapełni pustki pomieszczenia" ${ }^{\prime 30}$. Puste, pozbawione emocji twarze, odzwierciedlają hermetycznie zamknięty przewód dopływu emocji, emocje są tłumione. Wówczas dochodzi do chłodnej kalkulacji i reifikacji kontaktów. Myślenie dyskursywne, intelektualne gry językowe są przydatne społecznie, a uczucia niekoniecznie, dlatego też częstokroć są trzymane w niewoli analitycznego namysłu. Nieustanne manifestowanie czysto rozumowego podejścia do życia i ograniczanie dopływu emocji, mogą świadczyć o braku pewności siebie i przyjmowaniu postawy defensywnej wobec siebie i otoczenia, czego źródłem jest lęk egzystencjalny. Tysiąc sztucznych kwiatów mają być satysfakcjonującą imitacją naszego życia? Czy raczej nie jest tak, jak podkreślił pisarz Heinrich Böll, że

okazywanie [emocji - A.K.] jest traktowane niemal jak choroba. Ta antyuczuciowa filozofia może pociagnąc za sobą wymóg bycia bezwonnym albo konieczność nieograniczonej przydatności. W istocie jest to jak nekrolog. Kto utracił emocje, ten jest martwy ${ }^{31}$.

Można pokusić się o stwierdzenie, iż aby „ożywić pustynię”, ludzkość winna odrzucić wykreowane, otępiające i sztuczne role społeczne. W swych pracach Frankl często powołuje się na Karla Jaspersa, który ujmuje człowieka jako „byt rozstrzygający”, który nigdy po prostu nie jest, lecz nieustannie rozstrzyga, czym jest. Oczywiście, w tym przy-

28 Zob. A. Camus, Obcy, Wydawnictwo Zielona Sowa, Warszawa 2003.

29 M. Kundera, Niewiedza, Państwowy Instytut Wydawniczy, Warszawa 2003, s. 30 .

30 P. Lauster, Odwaga bycia soba, Świat Książki, Warszawa 1996, s. 93.

31 Ibidem. 
padku człowiek odziany jest w określone środowiskowe wzorce, dziedziczy pewne skłonności ${ }^{32}$. Jednakże, kategoria samotranscendencji, czyli wykraczania poza swój subiektywnie umeblowany świat w kierunku obiektywnie istniejących wartości i celów, może doprowadzić do upodmiotowienia międzyosobowych stosunków.

Frankl podkreśla, iż powinniśmy uczyć się od człowieka z ulicy, od jego prerefleksyjnego, ontologicznego rozumienia samego siebie, czym w ogóle jest bycie człowiekiem. Musimy uczyć się od mądrości jego ser$\mathrm{ca}$, że bycie człowiekiem oznacza nieustanną konfrontację z sytuacjami. Człowiek z ulicy wie, że bycie człowiekiem oznacza bycie odpowiedzialnym za wypełnienie sensu zawartego potencjalnie w danej sytuacji życiowej. Co ważniejsze, człowiek ów wie, że sens można znaleźć nie tylko w tworzeniu dzieła i spełnianiu czynu, nie tylko w spotkaniu kogoś i doświadczaniu czegoś, lecz również, jeśli trzeba, w sposobie, w jakim znosimy cierpienie. A co z człowiekiem informacyjnym, który z szybkością światła stara się pobieżnie poznać wszystko dookoła, wznosząc na piedestał zachowania ekstrawertyczne? Czyż nie jest to bezrefleksyjna próba samointerpretacji? Kolejną istotną wartością jest samorealizacja. Ostatecznie jednak człowiek może realizować siebie tylko wypełniając sens w świecie zewnętrznym raczej niż w samym sobie, a samorealizacja jest osiagalna jedynie jako skutek samotransendencji. Frankl zobrazował to następująco:

Podobnie jak bumerang powraca do myśliwego tylko wtedy, gdy chybia celu, człowiek powraca do siebie, zastanawia się nad sobą i zaczyna zbytnio zajmować się samointerpretacją tylko wtedy, gdy niejako uchybia swej misji doznaje zawodu w swym poszukiwaniu sensu ${ }^{33}$.

Jednakże, jak uzasadnia Kazimierz Obuchowski, nie każde zaangażowanie $\mathrm{w}$ dane zadanie i posłannictwo ma charakter treściorodny i niesie za sobą pozytywne, albowiem kształtujące osobowość konstruktywne składniki. Rozwój osobowościowy polegał będzie tutaj na umiejętności wyboru takiej alternatywy, która wcielona w życie, spowoduje jego wzrastanie. Czytamy:

Nadrzędne dążenie może z czasem stać się czynnikiem uprzedmiatawiającym jednostkę. Dla polityka najważniejsza jest opinia jego wyborców, dla gangstera władza, a dla wielkiego generała jego wielka bitwa, i to jest nie tylko ograniczenie. W naszej historii kosztowało to już niemało i nas,

32 "Człowiek jest zależny zarówno od swoich dziedzicznych skłonności, jak i środowiska, i może się swobodnie poruszać tylko w ramach wyznaczonych przez jedno i drugie. W ramach tych porusza się wszelako właśnie w sposób wolny" (zob. Frankl 1978).

33 E. Frankl, Nieuświadomiony Bóg, PAX, Warszawa 1978, s. 124-125. 
i samych polityków i generałów. To nadrzędne dążenie zbyt łatwo staje się celem samym w sobie, uprzedmiotawiając ich. Stają się narzędziem narzuconego przez rolę zbyt konkretnego marzenia. Oznaczałoby to, że sens życia powinien być nie tylko nadrzędną idea, obsesją spełnienia się w roli, ale przede wszystkim koncepcją życia powstałą jako wynik przemyślenia tego, czym jest dla nas życie, czym jest świat i człowiek w nim, i tego, co jest w naszym życiu naprawdę ważne ${ }^{34}$.

Również twórca Człowieka intencjonalnego wskazuje na znaczący wkład Frankla w problematykę psychologii sensu ${ }^{35}$. Czytając wiedeńskiego myśliciela nasuwa się spostrzeżenie, iż przytaczany przez niego człowiek współczesny jest raczej marionetką miotaną siłami z zewnątrz i wewnątrz, co stanowi zaprzeczenie humanistycznego sposobu percypowania. Pomimo, iż Kazimierz Obuchowski przedstawia poglądy Frankla, stwierdzając, że są one dopełniające względem panującego paradygmatu poznawczego i psychodynamicznego, to obarcza je niewyszukaną krytyka, co moim zdaniem, mija się z holistycznym i noetycznym obrazem człowieka.

Mimo całej retoryki Frankla jego odhomunkulusowany człowiek jest przedmiotowy, bierny, ograniczający się do zgody na predestynację wynikającą z nadsensu. Nie potrafię się $\mathrm{w}$ tym dopatrzyć ani intencjonalności, ani duchowości ${ }^{36}$.

Pytanie o sens egzystencji, zdaniem Obuchowskiego, jest uprawomocnione tylko wówczas, kiedy zapytujemy o własne zobowiązania sytuacyjne i obecne odniesienia do środowiska zewnętrznego. Działanie sensowne kojarzy się każdemu z osobna z realizacją określonych powinności, zaś działanie pozbawione sensu z mijaniem się od obowiązków, co obciąża nas cechą nieodpowiedzialności ${ }^{37}$. Faktem jest, iż Obuchowski krytykuje ewolucję mówiąc, iż jest ona „ślepa niczym bogini sprawiedliwości"38. Ewolucja faworyzuje osoby lepiej przystosowane genetycznie do środowiska naturalnego. Dlatego też, na piedestale stawiana jest radosna mutacja genów niż osobiste osiągnięcia jednostek. Ludzkość mierzy się z tymi upodobaniami. Zaznacza, iż tylko od każdego indywiduum zależy jego klasa i „przed nikim nie da się usprawiedliwić omyłki zaniechania bycia tym, kim można być" ${ }^{\prime 39}$.

34 K. Obuchowski, Przez galaktykę potrzeb. Psychologia dążeń ludzkich, Zysk i S-ka, Poznań 2000, s. 249.

35 Ibidem, s. 261.

36 Ibidem, s. 264.

37 Ibidem, s. 261.

38 Ibidem, s. 318.

39 Ibidem. 
Frustracja i pustka egzystencjalna, mroczna wegetacja to elementy niszczące sensowny wymiar życia. Nuda w ujęciu Moravii ukazuje nam świat emocjonalnego chaosu i braku dopasowania do zastanej rzeczywistości. Między człowiekiem, światem artefaktów oraz innymi nie dochodzi do prawdziwego spotkania. Człowiek nudzi się, pożąda czegoś, potrzebuje, jednak nie potrafi do końca doprecyzować, czego chce, co rodzi rozczarowanie i zaburzenia woli. Życie wydaje się nonsensem i ma charakter rozsypanych puzzli, których nie da się poukładać, gdyż brakuje ważnych części tej układanki.

Niezobowiązujące kontakty seksualne nie dają poczucia ulgi, rodzą egzystencjalny lęk przed bliskością i zobowiązaniem. Nuda rodzi się z psychicznej nieudolności i wewnętrznej niezdolności bycia tym, kim chciałoby się być. Nuda to emocjonalna ambiwalencja, interpersonalny chłód nie mogący przebić się przez mur niemocy. Nuda przypomina tutaj nieuważne życie podobne do snu lunatyka. Jednak "nudne” życie to rodzaj zawieszonej uwagi. Jesteśmy w pełni świadomi tego stanu rzeczy ${ }^{40}$. Viktor Frankl jako przedstawiciel psychologii egzystencjalnej niejednokrotnie podkreślał, że sensowne życie ma charakter procesu. Tożsamość rozproszona, pustka emocjonalna to konsekwencje obsesyjnych i przedmiotowych odniesień. Frankl (w swym dziele pod tytułem Homo Patiens) kładzie nacisk na przejawy redukcji bytu, co odnosi się do trzech postaci współczesnego nihilizmu: fizjologizm (redukcja do rzeczywistości fizycznej), psychologizm (redukcja do sfery psychicznej), oraz socjologizm (redukcja do przestrzeni społecznej) ${ }^{41}$. W każdej z tych sfer inny aspekt rzeczywistości zostaje całkowicie zmarginalizowany. Rzeczywistość zostaje sprowadzona do

samego tylko efektu, produktu i rezultatu faktów bądź fizjologicznych, bądź psychologicznych, bądź socjologicznych. Tak jednak, gdzie dostrzega się tylko sam efekt, nie można zobaczyć żadnej intencji, a gdzie się jej nie widzi, nie można też dopatrzyć się żadnego sensu ${ }^{42}$.

Moravia i Frankl reprezentują antagonistyczną wizję ludzkiej egzystencji. Moravia skupia się na aspekcie melancholijnym, pesymistycznym, wręcz przerażającym, gdzie kondycja ludzka przybiera postać zezwierzęcenia i niechęci do zmian. Frankl kładzie nacisk na usensowiony wymiar ludzkiej egzystencji, niezależnie od krępujących okoliczności. Człowiek jest istotą cierpiącą i niedoskonałą jednakże nudna i apatyczna egzystencja są konsekwencją postawy pozbawionej nadziei i defetystycznej. Praca w charakterze psychoterapeutycznym utwierdzi-

40 Zob. A. Moravia, Uwaga, Wydawnictwo Czytelnik, Warszawa 1968.

41 V.E. Frankl, Psychoterapia dla każdego, PAX, Warszawa 1978, s. 4.

42 V.E. Frankl, Homo Patiens, PAX, Warszawa, s. 9. 
ła Frankla, iż nie należy ignorować duchowego poziomu ludzkiej egzystencji. Pierwiastek psychosomatyczny (wymiar biologiczno-fizyczny połączony z psychicznym, charakteryzującym się sporą dawką subiektywizmu) jest zakotwiczony w wymiarze wyższym - duchowym (Geist). Noetyczny charakter przenika wymiar psychofizyczny, porządkuje go, dlatego winno mówić się o człowieku jako istocie duchowej. Mamy wtedy do czynienia z jednością w wielości - jest to unitas multiplex ${ }^{43}$. Mówiąc o człowieku jako jednostce duchowej, trzeba w założeniu przyjąć, że każde postępowanie człowieka na arenie pragmatycznych odniesień otrzymuje cechy swoiście ludzkie ${ }^{44}$. To właśnie nacisk kładziony przez Frankla na aspekt duchowy, który konstytuuje nasze bycie w świecie, stał się powodem konfliktu z Alfredem Adlerem. Kluczową pobudką metodologicznego zatargu z twórcą psychologii indywidualnej był fakt, iż Frankl akceptował potrzebę dopełnienia rozważań psychoanalitycznych refleksją filozoficzną. Fundamentalnie nakreślił, że wersja psychoterapeutycznego leczenia zaproponowana przez Freuda oraz Adlera istotnie nie jest $\mathrm{w}$ stanie objąć holistycznego obrazu ludzkich powinności, pragnień i złożoności jednostkowego bytu. Nuda u Moravii ma charakter chroniczny, ukazuje nam powolny znikający świat duchowości i głębszego wymiaru miłości. Relacja głównego bohatera i Cecylii przypomina szamotaninę dorosłych dzieci, u których nie wykształciły się zdolności do poprawnego i dojrzałego komunikowania się, co w konsekwencji przypomina banalną grę pozorowania bliskości. Stan nudy przyprawia Dino o nudności, ponieważ nie potrafi on doprecyzować, czego tak naprawdę chce. Czuje się wyalienowany i wewnętrznie rozdarty, kumulują się w nim przeciwstawne emocje, dlatego też zachowuje się bezmyślnie i nielogicznie.

Postindustrialne społeczeństwa przedstawiają model przyspieszonego życia przepełnionego manią ${ }^{45}$. Zachowania maniakalne nie stanowią kategorii psychiatrycznej czy zaburzenia, ale określoną postawę wobec życia: nadmierne pobudzenie psycho - motoryczne, mniejszą potrzebę snu, wzmożoną aktywność intelektualną i zadaniową a także myślenie życzeniowe. W tym przypadku stykamy się z jedną radykalną hipotezą. Po przeciwnej stronie znajduje się nuda, albowiem nużący stan uśpienia blokuje dostęp do stanów „przebodźcowania”.

Nasza koncepcja nudy - gnuśności, apatii. Ospałości, monotonii, znużenia, przygnębienia, chandry, mentalnego zastoju - to dość niedawny wy-

43 V.E. Frankl, Ärztliche Seelsorge. Deuticke, Wien 1966, s. 34.

$44 \mathrm{H}$. Kowol, Eucharystia odpowiedzia na naturalne potrzeby duchowe człowieka. Argumentacja teologiczna w świetle analizy egzystencjalnej Viktora Emila Frankla., Wyd. Uniwersytetu Warmińsko-Mazurskiego, Opole 2003, s. 52.

${ }^{45}$ J. Gleick, Szybciej: przyspieszenie niemal wszystkiego, Zysk i S-ka, Poznań 2003. 
nalazek. Słowo „nuda” jeszcze sto lat temu niemal nie istniało. Początkowo słowo „nudzić” oznaczało coś, co robiła inna osoba, w szczególności, gdy mówiła zbyt długo, powierzchownie i nie na temat ${ }^{46}$.

\section{Bibliografia}

Bauman Zygmunt, Płynna nowoczesność, Wydawnictwo Literackie, Kraków 2006.

Camus Albert, Obcy,Wydawnictwo Zielona Sowa, Warszawa 2003.

Frankl Viktor, Ärztliche Seelsorge, Deuticke, Wien 1966.

Frankl Viktor, Nieuświadomiony Bóg, PAX, Warszawa 1978.

Frankl Viktor, Psychoterapia dla każdego, PAX, Warszawa 1978.

Frankl Viktor, Homo Patiens, PAX, Warszawa 1984.

Frankl Viktor, Człowiek w poszukiwaniu sensu, Czarna Owca, Warszawa 2009.

Freud Sigmund, Poza zasada przyjemności, Wydawnictwo Naukowe PWN, Warszawa 2005.

James Gleick, Szybciej: przyspieszenie niemal wszystkiego, Zysk i S-ka, Poznań 2003.

Horney Karen, Neurotyczna osobowość naszych czasów, Rebis, Poznan 2006.

Jung Carl Gustaw, Wspomnienia, sny, myśli, WROTA i KR, Warszawa 1993.

Jung Carl Gustav, Archetypy i nieświadomość zbiorowa, Wyd. KR, Warszaa 2011.

Kowol Henryk, Eucharystia odpowiedzia na naturalne potrzeby duchowe człowieka. Argumentacja teologiczna w świetle analizy egzystencjalnej Viktora Emila Frankla, Wyd. Uniwersytetu Warmińsko-Mazurskiego, Opole 2003.

Kundera Milan, Niewiedza, Państwowy Instytut Wydawniczy, Warszawa 2003.

Lauster Peter, Odwaga bycia soba, Świat Książki, Warszawa 1996.

Moravia Alberto, Uwaga, Wydawnictwo Czytelnik, Warszawa 1968.

Moravia Alberto, Rzecz jest tylko rzecza, Wydawnictwo Czytelnik, Warszawa 1969

Moravia Alberto, Nuda, Nowy Kanon, Warszawa 2010.

Obuchowski Kazimierz, Przez galaktyke potrzeb. Psychologia dążń ludzkich, Zysk i S-ka, Poznań 2000.

Popielski Kazimierz, Noetyczny wymiar osobowości, Wyd. Uniwersyteckie KUL, Lublin 1994.

Sōseki Natsume, Sedno rzeczy, Państwowy Instytut Wydawniczy, Warszawa 1973.

Brazil (1985), reż. Terry Gilliam.

46 Ibidem, s. 271. 


\section{Streszczenie}

\section{Nuda egzystencjalna a sensowny wymiar człowieka}

\section{Słowa kluczowe}

nuda egzystencjalna; sens; wyobcowanie; frustracja; duchowość

Celem tego artykułu jest próba zdefiniowania pojęcia nudy w kontekście psychologii egzystencjalnej Viktora Emila Frankla oraz prozy psychologicznej Alberto Moravii. Nuda jako stan psychologiczny i postawa filozoficzna charakteryzuje się stagnacją zawieszeniem woli oraz brakiem zaangażowania. Frankl utożsamia nudę z brakiem sensu życia, z brakiem działania, zaś Moravia rozpatruje nudę $\mathrm{w}$ kontekście relacji interpersonalnych. Zdaniem psychologów egzystencjalnych nuda hamuje rozwój osobowy oraz przyczynia się do niemożności osiągnięcia satysfakcji życiowej.

\section{Summary}

\section{Existential boredom and sense of the human dimension}

\section{Keywords}

existential boredom; sense; alienation; frustration; spirituality

The aim of this article is an attempt to define the concept of boredom in the context of existential psychology of Viktor Emil Frankl and the psychological prose of Alberto Moravia. Boredom as a psychological state and philosophical attitude is characterized by stagnation, suspension of will, and lack of commitment. Frankl identifies boredom with no sense of life, with lack of action while Moravia considers boredom in the context of interpersonal relationships. According to existential psychologists boredom hampers personal development and contributes to inability to achieve life satisfaction. 